\title{
The Silent Revolution in Youth Political Engagement
}

The 2001 General Election marked a turning point in UK electoral politics. The dramatic decline in youth turnout led to the characterization of young people as, at best, apathetic abstainers, with little or no interest in democratic affairs. With respect to national elections, voter turnout prior to 2001 was a relatively stable affair; between 1945 and 1997, the mean turnout was $76 \%$ and varied on average by less than $4 \%$ between elections. However, in 2001, the landslide return of a Labour government was overshadowed by a collapse in electoral participation across the country. As Fig. 3.1 indicates, only $59 \%$ of the eligible electorate voted, down from $71 \%$ at the previous election in 1997 and falling to the lowest turnout rate since 1918 - an outcome interpreted by some as representing a 'crisis of democratic politics' (Harrop 2001; Whiteley et al. 2001). Although turnout increased in subsequent UK general elections, these changes were marginal, reaching only $61 \%$ in 2005 and $65 \%$ in 2010 - far short of the post-War average.

However, these headline turnout figures masked important patterns of electoral inequality. Many urban constituencies of high socio-economic deprivation, such as Liverpool, Leeds, Manchester and Glasgow, registered less than $45 \%$ turnout (UK Political Info 2018). Other social lines of difference were also apparent, as the unemployed, those from social classes $\mathrm{C} 2$ and DE, those living in the privately rented sector and those from British minority ethnic groups were each estimated to have voted in

(C) The Author(s) 2019

J. Sloam, M. Henn, Youthquake 2017, Palgrave Studies in Young

People and Politics, https://doi.org/10.1007/978-3-319-97469-9_3 


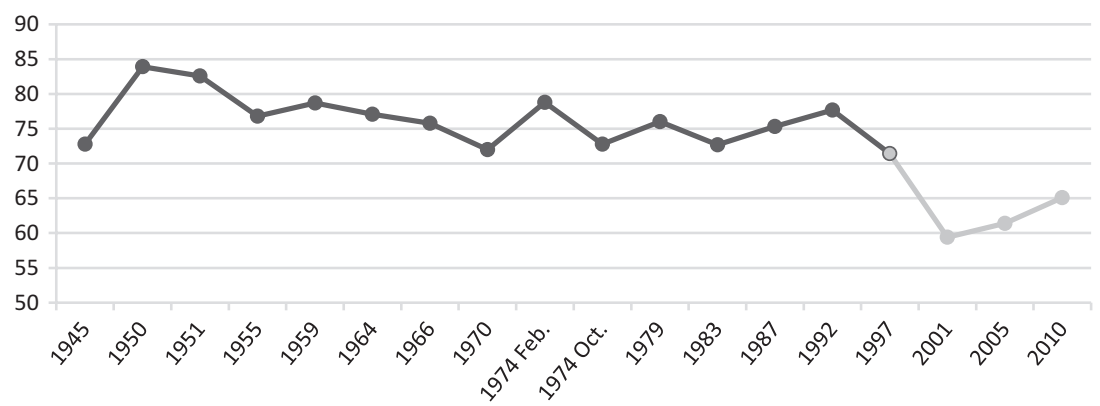

Fig. 3.1 UK general election turnout 1945-2010 (\%). (Source: UK Political Info 2018)

considerably lower numbers than their contemporaries (Ipsos MORI 2001; Electoral Commission 2002). These patterns of electoral inequality were broadly repeated at the general elections of 2005 and 2010 (Ipsos MORI 2005, 2010).

Age was also one of the strongest predictors of voter turnout. The extent of youth abstention from the polls was particularly apparent in 2001 , with only $39 \%$ of $18-24$ year olds voting, falling further to $37 \%$ in 2005 (Henn and Foard 2012) (see Fig. 1.1, Chap. 1). Although there was a slight increase to $44 \%$ in 2010 , by that time a discourse for youth politics of the new Millennium had become visible, largely centring on what young people were not doing - that they were failing to demonstrate an interest in formal politics (Park 2004) and were avoiding electoral politics (Russell et al. 2002).

However, a small number of studies published at that time challenged that analytical focus as well as the characterisation of youth political engagement and political participation that emerged from it. Authors claimed that such a representation of youth was based largely on a narrow conception of politics that failed to fully appreciate that young people were interested in matters that were essentially political in nature, even if they themselves did not articulate them as such (Henn et al. 2002; O'Toole et al. 2003). Furthermore, evidence suggested that young people were increasingly turning towards a variety of alternative political actions (Roker and Eden 2002), including 'cause-oriented' (Norris 2003) and 'micro-political' activities (Pattie et al. 2003). These new repertoires of political participation have been driven by underlying values change. 
As we shall see, Inglehart and Welzel (2005) attributed these developments to the rise of postmaterialist values in postindustrial democracies.

In this chapter, we consider patterns of youth political engagement and political participation in Britain between the 2001 and the 2010 General Elections, and observe a relatively stable level of interest in politics and importantly, a support for democracy that has endured over the period as the global economy has moved into deep recession. Nonetheless, we also identify an ongoing and deep antipathy towards the political class which may have repercussions in terms of the future weakening of the connection between young citizens and formal democratic institutions and processes - and ultimately the long-term viability of representative politics in the UK. Whilst this anti-political sentiment is present in younger generations in many other established democracies, the level of youth engagement - in comparison to older citizens - is far lower in the UK (see Fig. 1.2, Chap. 1).

Using two unique datasets (Henn and Weinstein 2003; Henn and Foard 2012), we seek out explanations for why these young Britons seem on the one hand to be sceptical of the value of elections and of the motives and performance of elected representatives, while on the other hand they seem genuinely attracted to new 'issue-based' agendas and alternative styles of politics. We also reveal that patterns of youth political engagement and political participation are not uniform. There is a tendency in much of the research to treat young people as a homogenised group, and in many respects that practice reflects a lack of large-scale studies of this demographic (as small samples prohibit the use of many statistical tests when conducting sub-sample analyses). However, as we are able to draw upon large samples of youth, this allows us to examine the interplay of several underlying factors considered to be associated with, and shaping, young people's political opinions, preferences and behaviours, including social class, gender, ethnicity and educational career. We are also able to assess the extent to which alternative value systems may have a bearing on youth politics. In particular, we address how new cultural cleavages - specifically, Inglehart's materialist-postmaterialist cleavage - are replacing these socio-demographic variables as the key drivers of young people's political engagement, and if these help to explain the emergence of young cosmopolitans and the unfolding youthquake. 


\section{Youth Political (Dis-)Engagement: Parties Fail TO CONNECT}

Explanations advanced for the apparent decline in youth participation in electoral politics are varied, and there is considerable disagreement as to the underlying causes. Hay (2007) usefully articulates the sources of this ongoing youth disaffection by offering 'demand-side' and 'supply-side' explanations. According to this, the demand for politics is rooted in people's changing values and outlooks. In particular, the rise of a more informed and critical citizenry (Norris 2011) who are increasingly frustrated with the limits of contemporary representative politics (Tormey 2015 ) - especially the under-performance of professional politicians (Whiteley 2012) - and are often pre-disposed towards more postmaterialist or cosmopolitan outlooks (Norris and Inglehart 2018). We shall discuss this in the second part of this chapter.

In contrast, supply-side explanations suggest that formal politics has failed to attract successive youth cohorts, not least because the policy concerns of young people are given little priority by politicians. For instance, Hart and Henn (2017) have claimed that in recent decades, mainstream parties in Britain have tended to coalesce around a broadly neoliberal philosophy that is committed to economic freedom above political freedom, and this has translated into a privileging of laissez-faire economic policies and a reduction in state intervention in the economy by successive governments (Berry 2012; Furlong and Cartmel 2012). As a consequence, the discourse and programmes of these parties have converged, offering very little in their party manifestos designed to improve young people's economic and social well-being or to champion the policy priorities and aspirations of the country's youth (Côté 2014; Sloam 2014; Busse et al. 2015). Moreover, there have been very few opportunities afforded to young people to shape the policy agendas of these political parties (Mycock and Tonge 2012), and this has tended to exacerbate the on-going and deepening disconnect between young people and democratic politics in Britain.

Analyses of the content and rhetoric of election manifestos for the UK General Elections of 2001 and 2010 provide insights into the extent to which the main national political parties - Labour, the Conservatives and the Liberal Democrats - reached out to young people as part of their campaigning. For both of these elections, we assessed the quantity of each party's content that attended to youth-related matters. For this purpose, 
we counted the number of times that the term 'Youth' or youth-related synonyms were mentioned as a proportion of the party document.

Table 3.1 summarises the results from these content analyses. They indicate that, during the early years of the new Millennium, all parties failed to offer a comprehensive, positive and consistent message of reassurance to young people that their concerns, hopes and aspirations would be addressed through government policy in the event that they were elected to office. These manifestos offered little incentive for young people to engage with the elections or to vote. Although the Labour Party mentioned young people (or synonyms of that generation) considerably more often in their 2001 election manifesto than did the Conservatives, their document was significantly larger in word length. When we examine the frequency of youth-related terms as a proportion of each manifesto, the differences are insignificant. Only $0.11 \%$ of the Labour manifesto mentioned young people, virtually identical to the Conservatives (0.11\%). By contrast, the Liberal Democrats referred to young people more than their main rivals $(0.14 \%)$, but again, the extent of the appeal to the youth electorate was negligible. Interestingly, each of the parties gave prominence to students (or 'graduates') over other young people (Labour 6 out of 35 mentions, Conservatives 10 out of 15 and Liberal Democrats 10 out of 29) - a group that has a considerably more middle class base, and is relatively likely to vote compared to the wider youth population.

In addition to the extremely low number of positive references to youth, the parties failed to offer substantial sections focussing on youth in their respective 2001 manifestos. Labour, as the outgoing party of government presented only a single bespoke youth passage, 'How Labour helps young people' that briefly listed six youth policy statements, including the New Deal and increased opportunities in higher education; however, this amounted to only 88 words and $0.29 \%$ of the manifesto. The Conservatives incorporated only a single equivalent youth-centred paragraph, focussing exclusively on 'Reducing barriers for students' (111 words, $0.84 \%$ ). The Liberal Democrats included a specific section devoted to higher education that represented a clear attempt to appeal to young people, 'Higher Education'. However, this amounted to only 262 words and $1.25 \%$ of the entire document; while they offered other youth-centred policies (including introducing voting at sixteen, entitlements to study leave with pay for all 16-24 year olds, extending the full Minimum Wage to all those aged 16 and over), each were dealt with as short headlines without detailed discussions. 


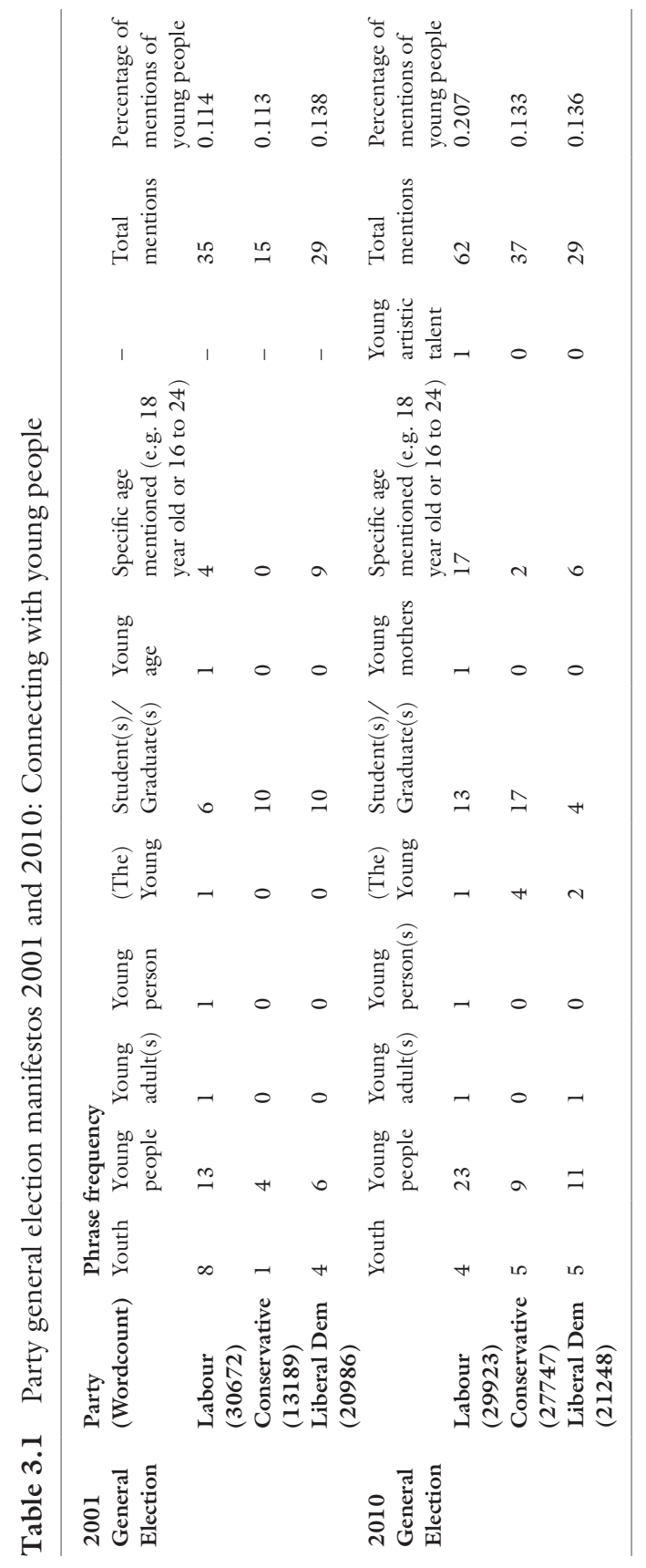


Analyses of the manifestos presented by the main national parties at the 2010 General Election suggested that each had learned relatively little from their collective failures to mobilise the youth vote a decade previously. The number of mentions of 'young people' and related terms in the Liberal Democrats' document were exactly the same as for 2001 (29 mentions and $0.14 \%$ as a proportion of the full manifesto). Arguably, the references to British youth in the Labour and Conservative manifestos each doubled (35-62 and 15-37, respectively), but again the proportion of the overall word count in each was considerably less than half of one percent. This reflected a distinct and quantifiable absence of direct appeals to young people.

Further examination of the manifestos suggests that youth-targeted themes formed a relatively minor aspect of each party's plans for government. The 2010 Conservative manifesto offered a noticeable change in tone from 2001, and included several policy appeals to young people. These included commitments to tackling youth unemployment, 20,000 new young apprenticeships, workplace training, the introduction of a National Citizen Service, and creating 10,000 additional university places by incentivising voluntary early re-payment of student loans. As in 2001, the Liberal Democrats again committed to reducing the voting age to 16. They also offered two brief bespoke youth-centred passages, to introduce a new youth work placement and apprenticeship schemes, and investment in Foundation Degrees and Adult Learning Grants. Labour, as the outgoing party of government, also offered brief reference to a small number of specific youth-targeted policies such as guaranteed employment for those out of work for six months or more, the right to supported housing for 16 and 17 year olds, a free vote in parliament on reducing the voting age to 16, and improved citizenship education. They also included a detailed section on education, which included raising the education and training leaving age to 18, retaining the Education Maintenance Allowance and a commitment that $75 \%$ of people would go 'on to higher education, or completing an advanced apprenticeship or technician level training, by the age of $30^{\prime}$.

Taken together, these manifesto analyses indicate a distinct lack of engagement with youth policy concerns at both the 2001 and 2010 UK General Elections and little effort to directly appeal to young people. This evidence lends support to Hay's (2007) 'supply-side' explanation of young people's ongoing withdrawal from electoral politics in general - and of voting in particular - in the early years of the new Millennium, as a failure 
of the parties to connect with young people. Furthermore, young people felt frustrated and disenchanted following the election of the ConservativeLiberal Democrat coalition government in 2010. In particular, the decision of Deputy Prime Minister Clegg to reverse his party's high-profile election campaign pledge to abolish university tuition fees and to vote instead for a three-fold rise, prompted a wave of anger amongst young people, including its manifestation in a nationwide wave of student protests in 2010 and 2011 (Hopkins et al. 2011). As a direct consequence of the Liberal Democrat U-turn on tuition fees and participation in the Coalition Government, its share of the youth vote collapsed from $30 \%$ in 2010 to just 5\% in 2015 (Ipsos MORI 2010, 2015). The Coalition Government's implementation of a far-reaching austerity programme in 2010 in response to the unfolding global economic crisis had a disproportionately negative impact on young people, and served to intensify existing generationally-based social and economic inequalities (Birch 2013). The impact of these policies left many young people feeling ignored and marginalised, contributing to their deepening mistrust of, and antipathy toward the political class, and a continued withdrawal from electorallyoriented politics (Henn and Foard 2014), and pushed those young people who did turn out to vote to switch to the Labour Party in 2015 and 2017 (see Chap. 5).

\section{Youth Political Apathy or Engaged Scepticism?}

A recurring theme in the youth studies literature is how best to characterise this apparent disconnect between young people and formal democratic politics in Britain. One position holds that their lack of presence in elections is indicative of political apathy or even of an emerging anti-politics sentiment. On the other side of this debate are those who consider this to represent young people's deep-seated feelings of alienation from, and dissatisfaction with, mainstream electoral politics and (for some) of their turn toward alternative political interests and repertories (see, for instance: Stoker 2006; Hay 2007; Sloam 2007; Farthing 2010; Phelps 2012; Bastedo 2015; Busse et al. 2015; Henn and Oldfield 2016). In this book, we take the position that British youth feel frustrated with the practice of, and outcomes from, representative politics. For some, their abstention from the polls reflects this disillusionment. For others - particularly young left-cosmopolitans - there is an active search for the co-production of a new style of politics (electorally-orientated or otherwise) that is more accessible, 
flexible and bottom-up and which offers them a route to actualise their ambitions and aspirations.

Using data from two unique and linked studies that focus on the views and priorities of separate cohorts of British youth, we can see that this youth scepticism of professional politicians and mainstream national political parties was an ongoing feature of the democratic landscape throughout the first decade of the new Millennium. The first study was conducted in 2002 (Henn and Weinstein 2003) during an era of relative global prosperity, whilst the second study was completed in 2011 at the height of the current financial crisis (Henn and Foard 2012). ${ }^{1}$ Both were representative questionnaire surveys conducted across England, Scotland and Wales exactly a year after preceding General Elections in 2001 and 2010, and all participants were aged 18 at the time of each respective election. Consequently, survey respondents were newly-enfranchised adult citizens when taking part in our study, all with no prior experience of voting. They were therefore relatively politically inexperienced in comparison with their older contemporaries, and were consequently less likely to have formed deep-seated views about politics, parties and politicians. The 2002 sample included 705 young people, and the 2011 study involved 1,025 young respondents.

The results indicate that, contrary to expectations, both the 2002 and the 2011 youth samples expressed an interest both in politics in general (56\% and 63\% respectively) and in the previous General Election (48\% and $64 \%$ ), although the 2011 cohort were clearly more engaged. However, half of the participants in each of the two samples lacked confidence in their own understanding of government and politics (55\% in 2002 and $50 \%$ in 2011 ), perhaps explaining the absence of many young people from the polls. Importantly, the young people in each of the studies felt politically powerless and considered that they had relatively little opportunity to intervene in the formal political process or to influence governmental decision- and policy-making (82\% in 2002 and 61\% in 2011). Although these findings represent a reduction in the sense of fatalism between the two elections, it offers a clear indication that British youth continued to feel alienated from the centres of political power.

It is therefore surprising that the data reveal that the larger group of young people in each of the two studies felt committed to elections (48\% in 2002 and $56 \%$ in 2011 ), although a sizeable minority in each group were sceptical (35\% and $37 \%)$. However, that broad support for the electoral process did not translate directly into positive views of the intrinsic 
value of elections. Indeed, only about a third of young people in both groups (28\% in 2002 and $36 \%$ in 2011 ) agreed with the statement that by voting they 'could really help to change the way that Britain is governed'. And, noticeable majorities agreed with the sceptical statement that 'elections allow voters to express their opinions but don't really change anything' $(60 \%$ and $57 \%)$.

Most revealing within the data was the perception held by young people of the political elites elected to represent their interests in Parliament. Fig. 3.2 indicates that the young participants in the two studies disapproved of the political class for failing to champion their policy interests and aspirations. They considered parties and politicians to be cynical political operators, 'only interested in people's votes, not in their opinions' and who 'soon lose touch with people' once an election is over. Related to these findings are the overwhelming levels of scepticism expressed by the 2011 cohort $^{2}$ with respect to their lack of trust in the UK Government (only $15 \%$ trust), political parties ( $8 \%$ trust) and politicians (7\% trust).

Taken together, the findings from the survey signal that young people's absence from elections and party-based politics is far from indicative of a generalised and inevitable political apathy - or that they are anti-democratic.

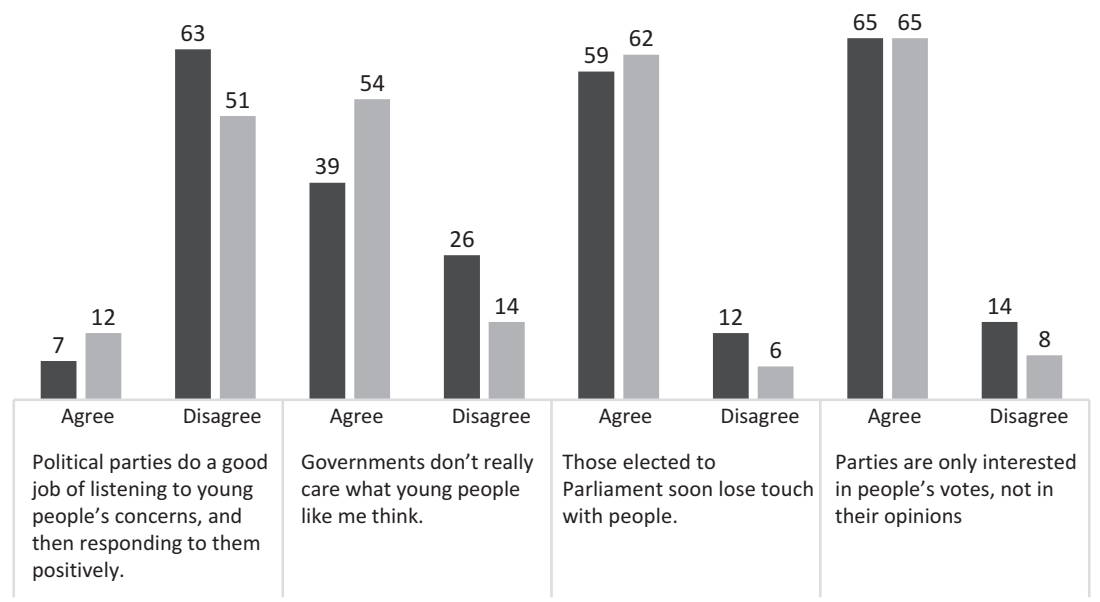

Fig. 3.2 Faith in political parties and professional politicians (\%). (Source: Henn and Foard (2012). $N=705$ (2002) and 1,025 (2011)) 
Instead, these data suggest that British youth are interested in politics but they feel relatively powerless to intervene in the political process. Furthermore, they find the practice of, and outcomes from, formal electorally-oriented politics deeply unsatisfactory, and feel that those political parties and professional politicians charged with conducting politics on their behalf are a remote, cynical and self-serving elite, paying little regard to the concerns and agendas of contemporary youth.

\section{The Silent Revolution in Youth Political ENGAGEMENT}

In the first part of this chapter, we considered a 'supply-side' approach that seeks to explain young people's apparent disconnection from mainstream politics in terms of their broad alienation from, and rejection of party-dominated electoral politics that they perceive as consistently failing to represent the priorities and aspirations of their generation. We now turn to an alternative explanation (Hay 2007) that views young people's withdrawal from mainstream politics as a consequence of the interplay of a series of 'demand-side' factors which are rooted in changing values and the emergence of a critical youth citizenry. In particular, the changing nature of contemporary British society is such that young people's lives, perspectives and behaviour are increasingly complex, risky and uncertain (Giddens 1991). Reflecting these processes, they often adopt individualised values and lifestyles which result in them privileging issue-based and identity politics over grand narratives. They are also inclined to embrace alternative forms of non-institutionalised and extra-parliamentary modes of political action discussed above. In the remaining sections of this chapter, we consider such an explanation. This has its origins in Ronald Inglehart's postmaterialist thesis, and emphasizes a cultural values-based cleavage as an alternative to traditional economic/industrial-based cleavages.

Conventional explanations of political participation and engagement have tended to focus upon people's socio-demographic characteristics, such as their social class, gender, ethnicity, and educational attainment (Verba and Nie 1972; Parry et al. 1992). Additionally, the linked civic voluntarism model stresses the importance of resources that individuals have at their disposal, including the time, money, and the opportunities to participate in politics - resources that may be structured by their 
socio-demographic background (Verba et al. 1995). In contemporary Britain, for instance, age when completed education (Whiteley 2012), educational qualifications (Tenn 2007), gender (Furlong and Cartmel 2012), social class (Pattie et al. 2004) and ethnicity (Heath et al. 2011) are all considered to impact upon political outlook and behaviour.

Inglehart's landmark study, 'The Silent Revolution in Europe' published in 1971, represented a critical departure from such socio-demographic explanations, and in particular, challenged the primacy of social class in the study of contemporary politics and society. He charted a transformation in the political value preferences that had occurred across West Europe between 1945 and the end of the 1960s (1971). He claimed that whereas their older contemporaries had been socialized through their experiences of post-War austerity into adopting priorities that emphasised their material and physical security, the youth of the 1960s had been socialised under very different economic prosperity conditions. Freed from the urgency of material acquisition, following sharp rises in living standards, they were able to focus on higher-order postmaterial matters, such as the protection of the environment, social justice, political reforms, and freedom of expression (Inglehart 1997).

Whilst age was considered to be a critical factor underpinning the emergence of materialist-postmaterialist cleavages, Inglehart also identified other key structuring variables. In particular, it was claimed that those from the new affluent middle class and those with extended formal educational experiences tended to have significantly higher levels of existential security than their working class and less highly educated contemporaries. As a consequence, these socio-demographic groups were considerably more likely to express postmaterialist value preferences (1971). Inglehart claimed that such developments represented the emergence of profound and long-term generational differences in value priorities that would culminate in the eclipse of social class -based conflict by newer materialist and postmaterialist cultural cleavages (Inglehart and Welzel 2005). Recently, Inglehart and Norris have reiterated this claim:

Today, many of the most heated conflicts are cultural - based on issues such as immigration, the threat of terrorism, abortion rights, same-sex marriage, and more fluid gender identities and support for progressive change on these issues increasingly comes from well-educated younger generations of Post-materialists, largely of middle class origin. (Inglehart and Norris 2016: 24) 
For Inglehart and his colleagues, the roots of this intergenerational cultural shift in political values lay deep in the changing economic conditions in which pre-adult socialization occurred (Inglehart 1990; Inglehart and Welzel 2005). As these post-War western societies underwent a transformation from economic austerity to relative prosperity, citizens socialized under such conditions would embrace postmaterialism over materialism, and this pattern would persist over time. Importantly, there was an appreciation that in times of economic austerity and crisis, the general trend toward postmaterialism and cultural modernization might be arrested, as citizens' subjective sense of economic security was undermined (Inglehart and Abramson 1994; Inglehart and Welzel 2005; Inglehart 2016). However, by the turn of the new millennium, he concluded that postmaterialism had grown in both stature and influence - even during periods of economic downturn, claiming that, "[ $\mathrm{t}]$ he age-related differences examined ... suggest that a process of intergenerational value change has been taking place during the past six decades and more' (Inglehart and Welzel 2005: 95; Inglehart 2008). More recently, analyses of data from the World Values Survey conducted by Abramson (2011), indicate an overall shift toward postmaterialism across Europe during the period 1970-2006.

\section{Postmaterialism and Contemporary Advanced INDUSTRIAL SOCIETIES}

The value of Inglehart's postmaterialist thesis has been the subject of significant debate. For instance, Flanagan et al. (2012) have presented recent evidence that intergenerational differences in patterns of political engagement are cyclical, and that when they enter later stages of adulthood, young people will participate in politics in ways that mirror the behaviour and preferences of their older contemporaries. Elsewhere, Grasso (2014) has rejected the postmaterial notion that young people's increasing withdrawal from mainstream electoral politics and their interest in alternative and transformative styles of politics is rooted within underlying economic prosperity or austerity conditions. Instead, she sees this as a reflection of the period effects in which they have been socialised, such as the ideological and volatile nature of contemporary societies.

Nonetheless, the thesis is widely considered to have offered a significant contribution to the field of social and political value change, and been 
found to be in evidence in a range of different social, economic and temporal contexts (Barnes et al. 1979; Klingemann and Fuchs 1995; Taniguchi 2006; Marthaler 2008; Janmaat and Braun 2009; Copeland 2014; Henn et al. 2017). Dalton (2009) has found similar patterns in his observations of a transition in the US from an 'Old' politics rooted in material scarcity concerns towards a 'New' politics characterised by expressive quality of life priorities. These new citizens are generally considered to be critically engaged with politics - albeit disillusioned with the performance of the political class (Norris 2011) and seeking social change. As Hay contends,

... the rise of post-material values has generated a better-educated, more savvy, less deferential and more critical electorate, less inclined to vote out of habit or out of simple respect for political authority, and less likely to be taken in by politics as a consequence. (Hay 2007: 154)

However, the current global economic crisis presents a considerable challenge to the growth of postmaterialist values in contemporary advanced industrial societies. Brym (2016: 195) claims that postmaterialism is not a universally advancing phenomenon, and in recent years has become 'a waning force among major world powers, giving way to increasing nationalism and xenophobia'. Similarly, Janmaat (2016) has recently concluded that there are no particular links between postmaterialist values and current austerity conditions across a range of European and western states. And, Cameron's (2013) analyses of data from the World Values Survey indicate a decline in postmaterialist values in several advanced democracies (though not in Britain) between 2005 and 2010.

Equally, patterns of materialist-postmaterialist value priorities within the youth population in Britain are not clear. Majima and Savage noted that throughout the 1990s, young people became progressively more materialist (2007). More recently, Theocharis (2011) claims that although there was a steady increase in young people's postmaterialist value preferences in Britain between 1981 and 2005, there has occurred a fall in such priorities since 2009 corresponding with the onset of the international financial crisis. Elsewhere, Rheingans and Hollands (2013) have even identified a merging of 'materialist' and 'postmaterialist' political values in the 2010 UK student movement. However, Henn et al. (2017) have recently concluded that the materialist-postmaterialist cleavage exerts a consistent and significant impact in terms of the shaping of young people's political participation preferences in austerity Britain. 
In Chap. 2 of this book, we drew upon the work of Henn et al. (2017) and Inglehart and Norris (2016) to demonstrate that there has indeed been a turn towards postmaterialism and an embrace of cosmopolitan-left values and politics by many British youth that is founded on a progressive cultural change. In the final section of this particular chapter, we develop this idea and examine patterns of political engagement since the turn of the new Millennium by focusing on the views and priorities of separate cohorts of British youth - the first study conducted in 2002 during an era of relative global prosperity, and the second completed in 2011 at the height of the current financial crisis. In doing so, we consider the variety of youth groups as well as whether (and if so how) their political values are structured by key variables during these contrasting periods. Finally, we assess the currency of Inglehart's thesis and whether or not postmaterialism offers an alternative explanation for youth political (dis-)engagement, as well as whether this is contingent on the economic context of their preadult socialization.

\section{Who Are the Young British Postmaterialists?}

In Chap. 2, we identified that postmaterialist values continue to play an important role in shaping the political participation preferences of many young people in Britain. But who are these young postmaterialists? Table 3.2 allows us to consider whether young people's materialistpostmaterialist outlooks are structured by their social class, education, gender or ethnicity, and if the relative power of these variables is linked to whether they were socialized under conditions of economic prosperity or austerity. We compare materialists, postmaterialists as well as a 'mixed' group who express both materialist and postmaterialist values. The findings indicate that ethnicity has little impact on the holding of materialistpostmaterialist value priorities. The 2002 sample reveals that there is a statistically significant gender gap under conditions of relative economic security, with young men considerably more materialist than young women $(p=0.044)$. However, the findings from the 2011 study suggest that young men and women socialized under conditions of economic scarcity are equally as likely to prioritise materialist concerns, and to deemphasise postmaterialist concerns $(p=0.254)$.

Inglehart's claims that social class and education are positively related to materialist-postmaterialist value priories are broadly reflected in Table 3.2. Under the relatively affluent economic conditions of 2002, 


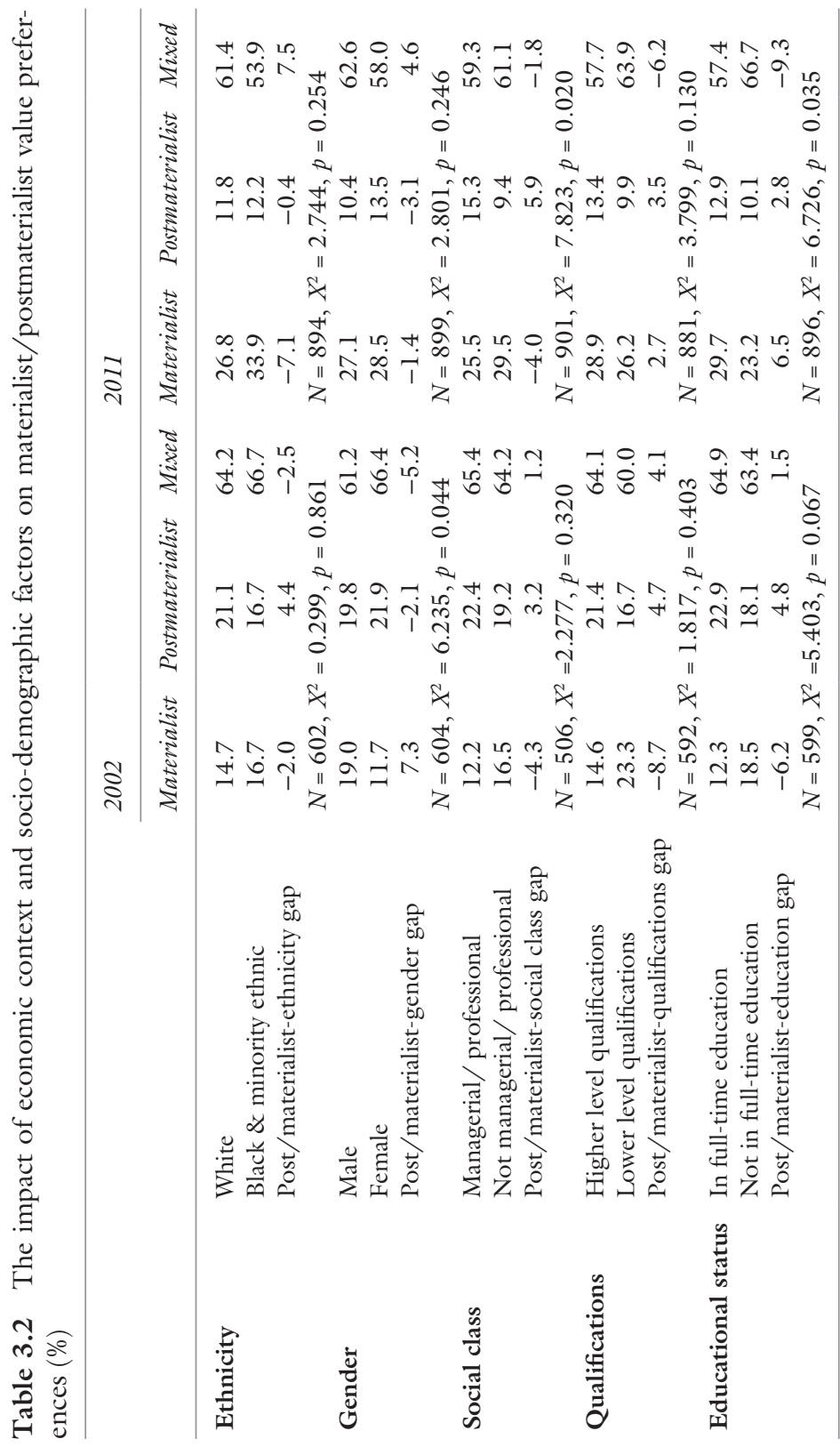


those young people from middle class managerial or professional households were more likely to prioritise postmaterialist values than were their working class contemporaries (22.4-19.2\%), and less likely to embrace materialist concerns $(12.2-16.5 \%)$. As expected, the relative size of support for postmaterialist values decreased a decade later as the economy moved into deep recession. Interestingly, this decline in the levels of postmaterialism was less steep amongst the managerial/professional group than for working class youth, and there was a relative increase in the Postmaterialist-social class gap that is statistically significant $(p=0.020)$. This strengthening of the post/materialist-social class gap identified in the 2011 youth sample suggests an enduring sustainability in postmaterialist value priorities among these British youth - even for those socialized under conditions of relative economic austerity.

There is no evidence that level of educational attainment has a statistically significant impact for either the 2002 or the 2011 samples $(p=0.403$ and $p=0.130$, respectively). However, remaining in full-time education beyond the age of 18 exerts an influence on young people's materialistpostmaterialist outlooks. As anticipated, those with extended periods of formal full-time education were more likely to hold postmaterialist values than were those who had opted to leave at an earlier age. This pattern is evidenced in the 2002 sample, and even to a lesser extent in the 2011 'economic austerity' cohort. Interestingly, when it comes to materialist values, the pattern is not consistent. Those remaining in formal education and emphasising materialist concerns outnumbered those who have left by a margin of 29.7-23.2\%. This particular finding might be explained by the concerns of those young people embarking on a university career following the 2010 announcement by the newly-elected Coalition Government to treble university tuition fees.

\section{Explaining Youth Political Engagement: Socio- Demographic and Postmaterialist Value Cleavages}

So far, we have established that there is a degree of continuing commitment by many young people to broadly postmaterialist concerns. We have also identified which groups within the youth population are most predisposed to a postmaterialist agenda - young postmaterialists are more likely than young materialists to be middle class and to have opted to stay in education beyond the age of 18 . This is the case regardless of whether they were socialized under conditions of relative material prosperity or during 
times of economic austerity. In order to better understand contemporary and unfolding patterns of youth political engagement, it remains for us to consider the importance of the materialist-postmaterialist value cleavage compared to other socio-demographic cleavages associated with the civic voluntarism model, including gender, ethnicity social class and educationbased differences.

Using hierarchical regression, Table 3.3 reveals that these sociodemographic variables display considerable predictive power for several aspects of political engagement, and for both of the time periods examined. In particular, there is evidence of statistically significant gaps with respect to gender, educational status and also social class location. However, the patterns between variables and across the time samples are not uniform.

As far as Political interest is concerned, young males, those who have opted to remain in full-time education, and those with a middle class background are considerably more interested than their counterparts. This is the case in both the 2002 and 2011 samples. Similar statistically significant gaps are present for gender, educational status and also social class factors at both time points for the Internal efficacy variable (which measures the degree of confidence that young people have in their own knowledge and understanding of politics). In addition, educational qualifications attained is also statistically significant for the 2011 cohort on this Internal efficacy variable. Those with higher level qualifications have more political selfconfidence than other youth.

There are some important patterns of association in terms of the sociodemographic backgrounds of the two youth cohorts and the three dependent variables that consider elections and voting. The Faith in the electoral process variable considers the extent to which young people feel that elections provide both an opportunity to have their voices heard by the political class, and also for holding politicians to account for any election promises made. Under the relatively affluent conditions experienced by the 2002 cohort, gender and also social class are both statistically significant predictors, with young males and those from middle class backgrounds more positive than other young people. For the 2011 'austerity' youth group, all of the five socio-demographic predictors bar social class have a significant bearing over this Faith in the electoral process variable.

The variable Value of elections, addresses perceptions that young people have of the effectiveness and veracity of elections as mechanisms for achieving meaningful societal change. Gender (2002 cohort) and also educa- 


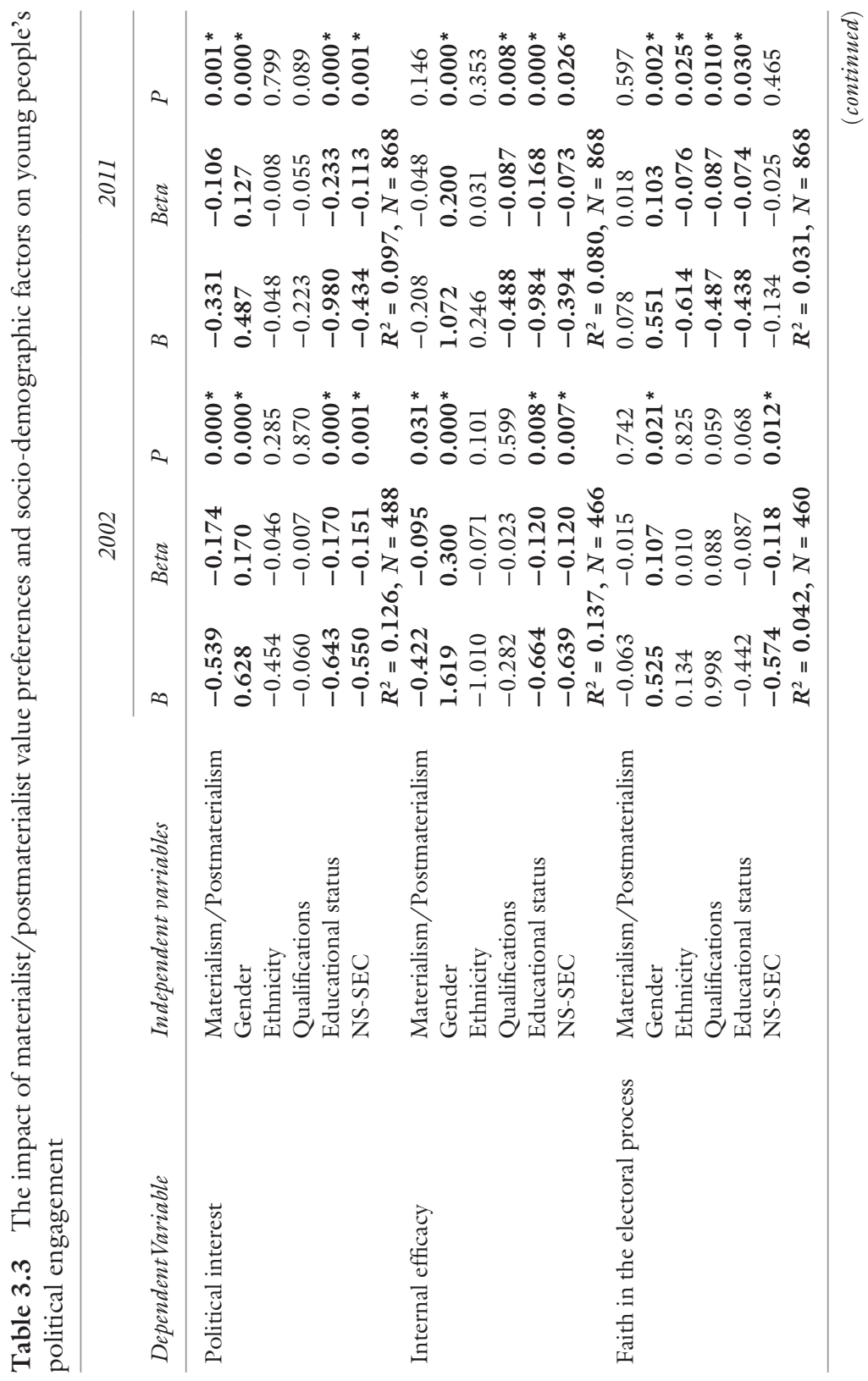




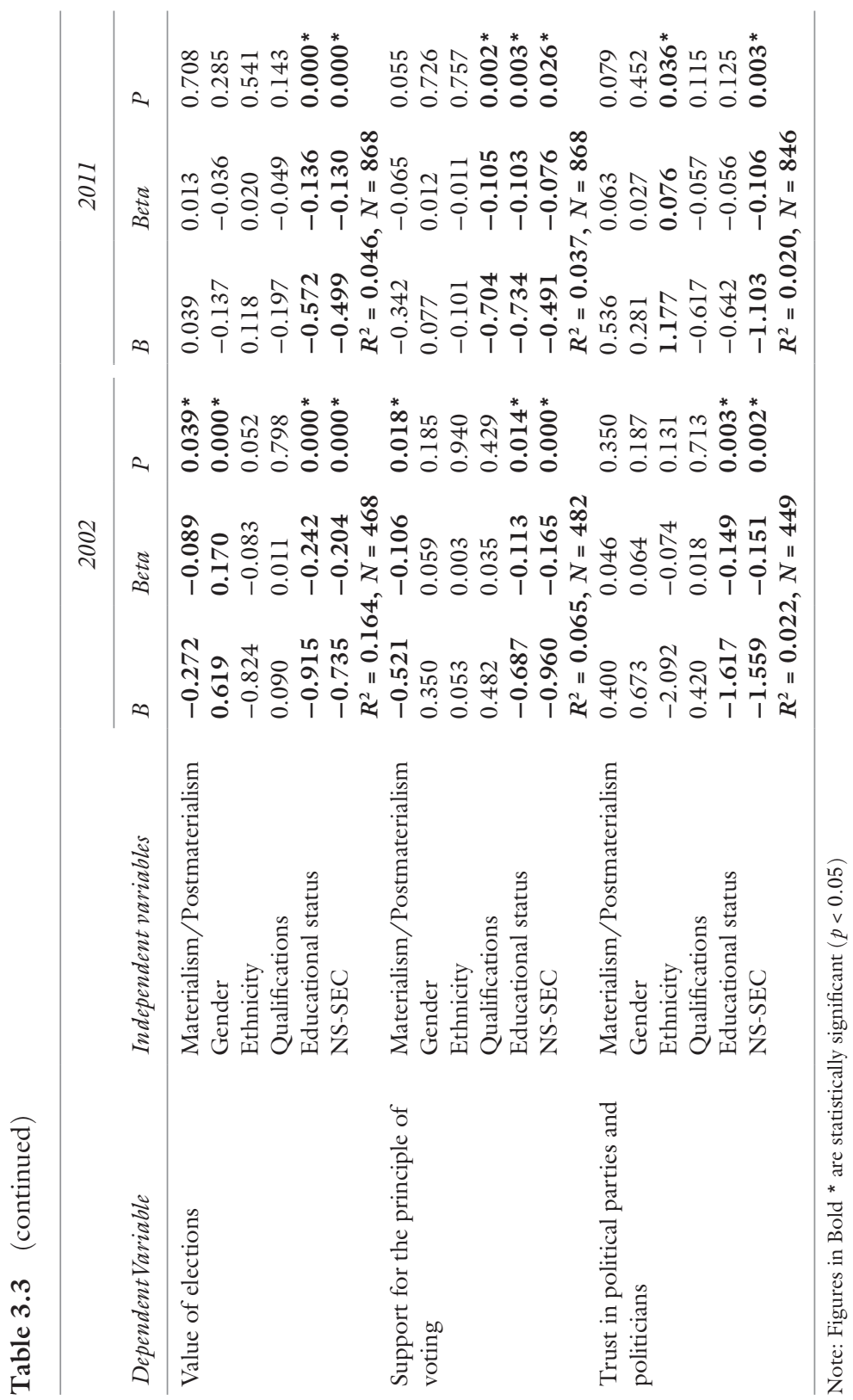


tional status and social class position (2002 and 2011) demonstrate statistically significant effects on this election variable, with young women, those from middle class backgrounds and those remaining in full-time education considerably more supportive than their contemporaries.

The third elections and voting variable, Support for the principle of poting, considers the extent to which young people feel that voting is satisfying, effective, and a duty of citizenship. Again, social class and educational status are statistically significant predictors, whether young people were socialized under conditions of relative economic affluence (2002) or of austerity (2011). Level of qualifications held is also a statistically significant predictor of this elections variable, but only in 2011.

Finally, there is evidence of socio-demographic background displaying some impact on youth perceptions of the political elite. Very few of the young people in our surveys expressed confidence in the political class. Nonetheless, there is a statistically-apparent social class gap on the question of their levels of Trust in political parties and politicians, with those from professional middle-class households considerably less critical than working class youth - this is the case for both the 'prosperity' and the 'austerity' samples. Elsewhere, the pattern is not uniform. Within the 2002 cohort, time spent in education exerts a statistically significant bearing on this trust variable, while there is also evidence of a significant ethnicity gap for the 2011 youth group. None of the other variables displayed a significant impact on young people's level of trust in the political class $(p>$ $0.05)$.

Table 3.3 also reveals that the materialist-postmaterialist cleavage had a notable predictive impact on young people's political engagement for the 2002 youth sample. These young postmaterialists are considerably more interested in politics and elections than their materialist counterparts. Equally, their levels of internal efficacy, the value that they place on elections and also their support for the principle of elections are each also statistically impacted by their materialist-postmaterialist preferences. As we would expect, results for the 2011 'austerity' cohort indicate that the materialist-postmaterialist cleavage has less predictive power than for the earlier cohort, reflecting the importance of underlying economic conditions in which pre-adult socialization occurred. Despite this, the materialistpostmaterialist cleavage did have a statistically-predictive impact on levels of political interest, with young postmaterialists significantly more interested than their materialist counterparts. 


\section{SUMMARY}

There was a dramatic drop in electoral turnout at the 2001 UK General Election that persisted throughout the first decade of the new Millennium. Importantly, this pattern of voting was socially and generationally uneven. Those living in constituencies of relatively high socio-economic deprivation, as well as traditionally marginalised groups such as the unemployed, social classes $\mathrm{C} 2$ and $\mathrm{DE}$, ethnic minorities, and people living in privately rented sector were particularly absent from the polls. However, the predominant electoral cleavage was generational, with young people considerably less likely than their older contemporaries to vote at the General Elections in 2001, 2005 and 2010.

This ongoing abstention from the polls fuelled a discourse within the media, academia and the corridors of Westminster that a politically uninterested and disengaged generation were withdrawing from the democratic process - and that they might carry their disenchantment with them into later life and in time replace older, more electorally-participative generations. Such concerns were succinctly summarised in a report from the House of Commons Political and Constitutional Reform Committee in 2014 which, drawing particular attention to young people, concluded that, "[D]emocracy is working less well than it used to and we need to move swiftly to pre-empt a crisis. The scale of the response must be equal to the task' (2014: 6). The advent of the global economic crisis at the end of the decade and the 2010 Coalition Government's programme of austerity hit young people particularly hard, and served to exacerbate their withdrawal from the electoral arena. High-profile policy U-turns such as the tripling of university tuition fees intensified young people's collective sense that the political class could not be trusted to champion their interests in Parliament.

But young people are not a homogenous group with a fixed and uniform view of democracy or of those who are elected to positions of political power. In this chapter we have observed that young people's political values and behaviours vary dramatically in terms of factors such as gender, ethnicity, social class and educational career. In particular, we have noticed that there is a specific group of young people - who are typically female, middle class and highly educated - who retain a strong commitment to postmaterialist priorities such as internationalism, environmentalism and social justice, and who are especially well-informed about, and critical of, 
British politics. These results are supported by our analyses of the 2016 EU referendum and the 2017 General Election in Chaps. 4 and 5.

As we would expect from Inglehart's thesis, the relative weight of support for postmaterialist preferences declined over the course of the first decade of the new Millennium, reflecting the transition from a youth socialization context of relative economic prosperity to one of economic insecurity following the onset of the global financial crisis. Nonetheless, even under austerity conditions, many young people continue to display a strong attachment to postmaterialist concerns and broadly cosmopolitanleft values and politics.

\section{Notes}

1. The 2002 data were derived from a postal questionnaire survey while the 2012 study involved an online survey.

2. These trust questions were only asked in the 2011 study.

\section{REFERENCES}

Abramson, P. R. (2011, March 11). Critiques and counter-critiques of the postmaterialism thesis: Thirty-four years of debate. Paper presented at the Global Cultural Changes Conference, Leuphana University, Luneburg.

Barnes, S. H., Kaase, M., et al. (1979). Political action: Mass participation in five western democracies. Beverly Hills: Sage.

Bastedo, H. (2015). Not 'one of us': Understanding how non-engaged youth feel about politics and political leadership. Journal of Youth Studies, 18(5), 649-665.

Berry, C. (2012). The rise of gerontocracy? Addressing the intergenerational democratic deficit. Intergenerational Foundation. Available at http://www.if.org. uk/wp-content/uploads/2012/04/IF_Democratic_Deficit_final.pdf. Accessed 23 Mar 2018.

Birch, S., Gottfried, G., \& Lodge, G. (2013). Divided democracy: Political inequality in the UK and why it matters. London: Institute of Public Policy Research.

Brym, R. (2016). After postmaterialism: An essay on China, Russia and the United States. Canadian Journal of Sociology, 41(2), 195-212.

Busse, B., Hashem-Wangler, A., \& Tholen, J. (2015). Two worlds of participation: Young people and politics in Germany. The Sociological Review, 63(S2), $118-140$.

Cameron, S. M. (2013, September). Postmaterialism in times of crisis. Paper presented at the European Consortium for Political Research General Conference, Bordeaux. 
Copeland, L. (2014). Value change and political action: Postmaterialism, political consumerism and political participation. American Politics Research, 42(2), 257-282.

Côté, J. E. (2014). Towards a new political economy of youth. Journal of Youth Studies, 17(4), 527-543.

Dalton, R. J. (2009). The good citizen: How the young are reshaping American politics (Revised ed). Washington, DC: CQ Press.

Electoral Commission. (2002). Voter engagement among black and minority ethnic communities. London: The Electoral Commission.

Farthing, R. (2010). The politics of youthful antipolitics: Representing the "issue" of youth participation in politics. Journal of Youth Studies, 13(2), 181-195.

Flanagan, C., Finlay, A., Gallay, L., \& Kim, T. (2012). Political incorporation and the protracted transition to adulthood: The need for new institutional inventions. Parliamentary Affairs, 65(1), 29-46.

Furlong, A., \& Cartmel, F. (2012). Social change and political engagement among young people: Generation and the 2009/2010 British election survey. Parliamentary Affairs, 65(1), 13-28.

Giddens, A. (1991). Modernity and self-identity: Self and society in the late modern age. Cambridge: Polity.

Grasso, M. T. (2014). Age, period and cohort analysis in a comparative context: Political generations and political participation repertoires in Western Europe. Electoral Studies, 33(1), 63-76.

Harrop, M. (2001). An apathetic landslide: The British general election of 2001. Government and Opposition, 36(3), 295-313.

Hart, J., \& Henn, M. (2017). Neoliberalism and the unfolding patterns of young people's political engagement and political participation in contemporary Britain. Societies, $7(4), 33$.

Hay, C. (2007). Why we hate politics. Cambridge: Polity Press.

Heath, A., Fisher, S., Sanders, D., \& Sobolewska, M. (2011). Ethnic heterogeneity in the social bases of voting at the 2010 British general election. Journal of Elections, Public Opinion and Parties, 21(2), 255-277.

Henn, M., \& Foard, N. (2012). Young people and politics in Britain: How do young people participate in politics and what can be done to strengthen their political connection. Economic and Social Research Council (award RES-000-22-4450) (2011-2012). Available at http://researchcatalogue.esrc.ac.uk/grants/RES000-22-4450/read. Accessed 1 Mar 2018.

Henn, M., \& Foard, N. (2014). Social differentiation in young people's political participation: The impact of social and educational factors on youth political engagement in Britain. Journal of Youth Studies, 17(3), 360-380.

Henn, M., \& Oldfield, B. (2016). Cajoling or coercing: Would electoral engineering solve the young citizen-state disconnect? Journal of Youth Studies, 19(9), $1259-1280$. 
Henn, M., \& Weinstein, M. (2003). First-time voters' attitudes towards party politics in Britain. Economic and Social Research Council (award R000223598) (2001-2003). Available at http://researchcatalogue.esrc.ac.uk/grants/ R000223598/read. Accessed 1 Mar 2018.

Henn, M., Oldfield, B., \& Hart, J. (2017). Postmaterialism and young people's political participation in a time of austerity. The British Journal of Sociology (advanced online publication).

Henn, M., Weinstein, M., \& Wring, D. (2002). A generation apart? Youth and political participation in Britain. The British Journal of Politics and International Relations, 4(2), 167-192.

Hopkins, P., Todd, L., \& Newcastle Occupation. (2011). Occupying Newcastle University: Student resistance to government spending cuts in England. The Geographical Journal, 178(2), 104-109.

House of Commons Political and Constitutional Reform Committee. (2014). Voter engagement in the UK, fourth report of session 2014-15. London: The Stationery Office Limited.

Inglehart, R. (1971). The silent revolution in Europe: Intergenerational change in post-industrial societies. American Political Science Review, 65(4), 991-1017.

Inglehart, R. (1990). Culture shift in advanced industrial society. Princeton: Princeton University Press.

Inglehart, R. (1997). Modernization and postmodernization: Cultural, economic and political change in 43 societies. Princeton: Princeton University Press.

Inglehart, R. (2008). Changing values among western publics from 1970 to 2008. West European Politics, 31(1-2), 130-146.

Inglehart, R. (2016). After postmaterialism: An essay on China, Russia and the United States: A comment. Canadian Journal of Sociology, 41(2), 213-222.

Inglehart, R., \& Abramson, P. (1994). Economic security and value change. American Political Science Review, 88(2), 336-354.

Inglehart, R. (2018). Cultural Backlash: The rise of Authoritarian populism. Cambridge: Cambridge University Press.

Inglehart, R., \& Welzel, C. (2005). Modernization, cultural change, and democracy: The human development sequence. New York: Cambridge University Press.

Ipsos MORI. (2001). How Britain voted in 2001. Available at https://www.ipsos. com/ipsos-mori/en-uk/how-britain-voted-2001. Accessed l Mar 2018.

Ipsos MORI. (2005). How Britain voted in 2005. Available at https://www.ipsos. com/ipsos-mori/en-uk/how-britain-voted-2005. Accessed l Mar 2018.

Ipsos MORI. (2010). How Britain voted in 2010. Available at https://www.ipsos. com/ipsos-mori/en-uk/how-britain-voted-2010. Accessed l Mar 2018.

Ipsos MORI. (2015). How Britain voted in the 2015 general election. Available at https://www.ipsos.com/ipsos-mori/en-uk/how-britain-voted-2015. Accessed l Mar 2018.

Janmaat, J. G. (2016). Values in times of austerity: A cross-national and crossgenerational analysis. Citizenship Teaching \& Learning, 11(3), 267-287. 
Janmaat, G. J., \& Braun, R. (2009). Diversity and postmaterialism as rival perspectives in accounting for social solidarity. International Journal of Comparative Sociology, 50(1), 39-68.

Klingemann, H. D., \& Fuchs, D. (1995). Citizens and the state. Oxford: Oxford University Press.

Majima, S., \& Savage, M. (2007). Have there been culture shifts in Britain? A critical encounter with Ronald Inglehart. Cultural Sociology, 1(3), 293-315.

Marthaler, S. (2008). "New" politics for "old"? Value change and the voter-party relationship in France. French Politic, 6(3), 187-213.

Mycock, A., \& Tonge, J. (2012). The party politics of youth citizenship and democratic engagement. Parliamentary Affairs, 65(1), 138-161.

Norris, P. (2003, November 27-28). Young people and political activism: From the politics of loyalties to the politics of choice? Report for the Council of Europe Symposium, Young people and democratic institutions: From disillusionment to participation, Strasbourg.

Norris, P. (2011). Democratic deficit: Critical citizens revisited. Cambridge: Cambridge University Press.

Norris, P., \& Inglehart, R. (2018). Cultural Backlash: The rise of Authoritarian populism. Cambridge: Cambridge University Press.

O’Toole, T., Lister, M., Marsh, D., Jones, S., \& McDonagh, A. (2003). Tuning out or left out? Participation and non-participation among young people. Contemporary Politics, 9(1), 45-61.

Park, A. (2004). Has modern politics disenchanted the young? In A. Park, K. Curtis, C. Thompson, C. Bromley, \& M. Phillips (Eds.), British social attitudes: The 21st report (pp. 23-48). Thousand Oaks: Sage.

Parry, G., Moyser, G., \& Day, N. (1992). Political participation and democracy in Britain. Cambridge: Cambridge University Press.

Pattie, C., Seyd, P., \& Paul Whiteley, P. (2003). Citizenship and civic engagement: Attitudes and behaviour in Britain. Political Studies, 51(3), 443-468.

Pattie, C., Seyd, P., \& Whiteley, P. (2004). Citizenship in Britain: Values, participation and democracy. Cambridge: Cambridge University Press.

Phelps, E. (2012). Understanding electoral turnout among British young people: A review of the literature. Parliamentary Affairs, 65(1), 281-299.

Rheingans, R., \& Hollands, R. (2013). "There is no alternative?": Challenging dominant understandings of youth politics in late modernity through a case study of the 2010 UK student occupation movement. Journal of Youth Studies, 16(4), 546-564.

Roker, D., \& Eden, K. (2002). '...doing something': Young people as social actors. Leicester: National Youth Agency.

Russell, A., Fieldhouse, E., Purdam, K., \& Kalra, V. (2002). Voter engagement and young people. London: The Electoral Commission. 
Sloam, J. (2007). Rebooting democracy: Youth participation in politics in the UK. Parliamentary Affairs, 60(4), 548-567.

Sloam, J. (2014). New voice, less equal: The civic and political engagement of young people in the United States and Europe. Comparative Political Studies, $47(5), 663-688$.

Stoker, G. (2006). Why politics matters: Making democracy work. Houndmills: Palgrave Macmillan.

Taniguchi, M. (2006). A time machine: New evidence of post-materialist value change. International Political Science Review, 27(4), 405-425.

Tenn, S. (2007). The effect of education on voter turnout. Political Analysis, $15(4), 446-464$.

Theocharis, Y. (2011). The influence of postmaterialist orientations on young people's offline and online political participation. Representations, 47(4), $435-455$.

Tormey, S. (2015). The end of representative politics. Cambridge: Polity Press.

UK Political Info. (2018). Voter turnout by constituency, 2001 general election. Available at http://www.ukpolitical.info/Turnout01.htm. Accessed 1 Mar 2018.

Verba, S., \& Nie, N. (1972). Participation in America. New York: Harper and Row.

Verba, S., Schlozman, K. L., \& Brady, H. E. (1995). Voice and equality: Civic voluntarism in American politics. Cambridge, MA: Harvard University Press.

Whiteley, P. (2012). Political participation in Britain. Basingstoke: Palgrave Macmillan.

Whiteley, P., Clarke, H., Sanders, D., \& Stewart, M. (2001). Turnout. In P. Norris (Ed.), Britain votes 2001. Oxford: Oxford University Press.

Open Access This chapter is licensed under the terms of the Creative Commons Attribution 4.0 International License (http://creativecommons.org/licenses/ by $/ 4.0 /)$, which permits use, sharing, adaptation, distribution and reproduction in any medium or format, as long as you give appropriate credit to the original author(s) and the source, provide a link to the Creative Commons license and indicate if changes were made.

The images or other third party material in this chapter are included in the chapter's Creative Commons license, unless indicated otherwise in a credit line to the material. If material is not included in the chapter's Creative Commons license and your intended use is not permitted by statutory regulation or exceeds the permitted use, you will need to obtain permission directly from the copyright holder.

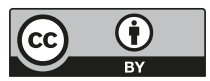

